\title{
JOHANNES PAHLITZSCH
}

\section{The Mamluks and Cyprus: Transcultural Relations between Muslim and Christian Rulers in the Eastern Mediterranean in the Fifteenth Century}

With regard to transcultural transfer the Mamluks represent a particularly revealing example in several respects. As military slaves of non-Muslim origin brought to Cairo as prisoners of war or slaves from a variety of various regions for training and Islamic education, they exemplified a perfect case of transcultural exchange. They did not completely abandon their native languages and customs; in fact, their wives often also came from their countries of origin. At the same time, however, after the establishment of Mamluk rule and the conquest of the crusader principalities in the course of the thirteenth century, the Mamluks pursued a policy that was essentially focused internally, on the maintenance of power, rather than on expansion. Thus, according to Stephen Humphreys, the Mamluk sultanate was a model of a fortress state ${ }^{1}$. This means that the Mediterranean trade was left entirely to the Christian merchants, especially those from Venice, and that the Syrian ports and coastal towns were stripped of any fortification for fear that a new crusade could establish bases there for further conquest of the country $^{2}$. According to David Ayalon, the Mamluks' attitude to the sea was decidedly negative $^{3}$. The approach taken by the historiography of the Mamluk period - which lay above all in the hands of the Islamic religious scholars (the ulama $)$, who adopted a fundamentally Islamic perspective, and which served also to legitimize the rule of the Mamluks by portraying them as defenders of Islam and as pious Muslims - accords with this turning away from the Mediterranean and Christian Europe by the Mamluks ${ }^{4}$.

1 R. Stephen Humphreys, Ayyubids, Mamluks, and the Latin East in the Thirteenth Century, in: Mamlūk Studies Review 2 (1998), p. 1-17, 13; ID., The Politics of the Mamluk Sultanate. A Review Essay, in: Mamlūk Studies Review 9/1 (2005), p. 221-231, here p. 226.

2 See, in general, Albrecht FuESS, Verbranntes Ufer. Auswirkungen mamlukischer Seepolitik auf Beirut und die syro-palästinensische Küste (1250-1517), Leiden, Boston, Cologne 2001 (Islamic History and Civilization. Studies and Texts, 39); ID., Rotting Ships and Razed Harbours. The Naval Policy of the Mamluks, in: Mamlūk Studies Review 5 (2001), p. 45-71.

3 David AYALON, The Mamluks and Naval Power. A Phase of the Struggle between Islam and Christian Europe, in: Proceedings of the Israel Academy of Sciences and Humanities 1/8 (1965), p. 1-12. See also FuESS, Verbranntes Ufer (as in n. 2), p. 91-101, who discusses Ayalon's arguments.

4 For the 'ulama ' and the stylization of the Mamluks as ideal Muslims see Jonathan BERKEY, The Mamluks as Muslims. The Military Elite and the Construction of Islam in Medieval Egypt, in: Thomas PhilipP, Ulrich HAARMann (eds.), The Mamluks in Egyptian Politics and Society, Cambridge 1998, p. 163-173; Yaacov LEV, Symbiotic Relations. Ulama and the Mamluk Sultans, in: Mamlūk Studies Review 13/1 (2009), p. 1-26, http://mamluk.uchicago.edu/MSR_XIII -1_2009-Lev_pp1-26.pdf (26/3/2012); Jonathan BERKEY, Mamluk Religious Policy, in: Māmlūk Studies Review 13/2 (2009), p. 7-22, http://mamluk.uchicago.edu/MSR_XIII-2_2009-Berkey_ 
Taking the example of the Mamluk relationship to the kingdom of Cyprus in the fifteenth century, this article examines the supposedly clear definition of the Mamluk state's foreign relations by focusing on the diversity of relations across cultural boundaries, particularly on a personal level. After the conquest of Acre in 1291, the Mamluks maintained quite good relations, especially with regard to commerce, with Cyprus, which profited from the papal trade embargo. Arabic-speaking Oriental Christians from Famagusta, who had emigrated to Cyprus on account of the Mongol and Mamluk conquests of Syria, acted as intermediaries and acquired great wealth. However, with the establishment of direct trade relations between the Mamluk state and Venice in the middle of the fourteenth century, the ultimately unsuccessful attack by Peter I on the Mamluk sultanate in the 1360s, and the conquest of Famagusta by Genoa in 1373, Cyprus lost its economic importance for the Mamluks 5 .

At the beginning of the fifteenth century, relations deteriorated further. The Cypriot king tried to compensate for the economic losses caused by the decline of trade by supporting piracy and raids on the Syrian coast. However, after the Mamluk sultanate had witnessed a period of disputes over the throne, Sultan al-Ašraf Barsbay (14221438) was able to devote himself to problems of foreign policy once more. The piracy pursued or supported by Cyprus was no longer tolerated and several fleets were fitted out which finally succeeded in conquering the island and capturing the Cypriot king Janus (1398-1432) in 14266.

pp6-22.pdf (26/3/2012). For Mamluk historiography in general, see Donald P. LITTLE, Historiography of the Ayyūbid and Mamlūk Epochs, in: The Cambridge History of Egypt, vol. 1: Islamic Egypt 640-1517, ed. Carl F. PETRY, Cambridge 1998, p. 412-444; and Nasser RABBAT, Representing the Mamluks in Mamluk Historical Writing, in: Hugh KENNEDY (ed.), The Historiography of Islamic Egypt (c. 950-1800), Leiden, Boston, Cologne 2001, p. 59-75.

5 Peter W. EdBury, The Crusading Policy of King Peter I of Cyprus, 1359-1369, in: Peter Malcolm Holt (ed.), The Eastern Mediterranean Lands in the Period of the Crusades, Warminster 1977, p. 90-105 [reprint in: ID., Kingdoms of the Crusaders. From Jerusalem to Cyprus, Aldershot 1999 (Variorum Collected Studies Series, 653)]; ID., The Kingdom of Cyprus and the Crusades, 1191-1374, Cambridge 1991. For Famagusta, see also Peter W. EDBURY, Famagusta in 1300, in: Nicholas COUREAS, Jonathan RILEY-SMITH (eds.), Cyprus and the Crusades. Papers given at the International Conference »Cyprus and the Crusades«, Nicosia 69 September 1994, Nicosia 1995, p. 337-353 (reprinted in: ID., Kingdoms of the Crusaders); Nicholas CourEas, Controlled Contacts. The Papacy, the Latin Church of Cyprus and Mamluk Egypt, 1250-1350, in: Jo VAn STEEnBERgen, Urbain Vermeulen (eds.), Egypt and Syria in the Fatimid, Ayyubid and Mamluk Eras 4. Proceedings of the 9th and 10th International Colloquium organized at the Katholieke Universiteit Leuven in May 2000 and May 2001, Leuven, Dudley 2005, p. 395-408; Albrecht Fuess, Was Cyprus a Mamluk Protectorate? Mamluk Policies Toward Cyprus Between 1426 and 1517, in: Journal of Cyprus Studies 11 (2005), p. 1124, 14-15. For oriental Christians in Cyprus, see Jean RICHARD, Le peuplement latin et syrien en Chypre au XIII ${ }^{\mathrm{e}}$ siècle, in: Byzantinische Forschungen 7 (1979) (= Freddy E. THIRIET (ed.), Mouvements de la Population et Problèmes de colonisation en Romanie Greco-Latine du $\mathrm{X}^{\mathrm{e}}$ au $\mathrm{XIII}^{\mathrm{e}}$ siècles. Symposion Byzantinon: Colloque international des historiens de Byzance 3, Strasbourg, 27-30 Septembre 1977), p. 157-173 (reprinted in: Jean RICHARD, Croisés, missionnaires et voyageurs, London 1983).

6 Peter W. EdBuRY, The Lusignan Kingdom of Cyprus and its Muslim Neighbours, in: Kypros apo ten Proistoria stous Neoterous Chronous, Nicosia 1995, p. 223-242 [reprinted in: ID., Kingdoms of the Crusaders (as in n. 5)]; Jean RICHARD, L'état de guerre avec l'Égypte et le 
However, before the final decisive expedition, there was apparently a last attempt to avert a further war. The Cypriot chronicler Leontios Machairas writes of a Damascene sheikh by the name of Ibn Qudaydār. Having heard many good reports of Janus thanks to his acquaintance with a Cypriot envoy and merchant, Ibn Qudaydār sent his son to Cyprus to mediate, because (according to Leontios Machairas) he "was not a man of war $\ll$ ? . Although the barons refused to admit the sheikh's son to Janus at first, he succeeded in having a secret letter from his father to the king read out by a translator. In this letter, the sheikh urgently warned the king of the superior strength of the sultan, who, he noted, was also in the right since the Cypriots had not fulfilled their commitment to take action against piracy. He wrote that he was doing all this because of his esteem for the king, although he was thus betraying his own faith and his lord, the sultan, a devout Muslim. However, on the barons' advice the king rejected the sheikh's efforts to mediate, which led (according to Leontios Machairas' account) to the sheikh finally declaring: »It must without doubt be the will of God that he shall abide under the lordship of my lord the sultan, and that he and his council shall be slaves of my lord because of their pride ${ }^{8} \ll$.

Even assuming that Leontios Machairas' description of the negotiations in Cyprus has a strong literary character in the sense that it tries to blame the barons for the coming disaster 9 , it is by no means improbable that such an attempt at mediation was undertaken by means of private contacts, regardless of who initiated them. Ibn Qudaydār, who seems to have been held in particularly high esteem, was especially suited for this role as he had already acted as a peace negotiator on various previous occasions, for instance during the occupation of Damascus by Timur and on the occasion of a peace treaty of 1414 between the Mamluks and Cyprus ${ }^{10}$.

royaume de Chypre, in: EDBuRY, Cyprus and the Crusades (as in n. 5), p. 83-96; FuESs, Verbranntes Ufer (as in n. 2), p. 30-40; ID., Was Cyprus a Mamluk Protectorate? (as in n. 5), p. $15-17$.

7 Leontios Machairas, Recital Concerning the Sweet Land of Cyprus Entitled »Chronicle«,

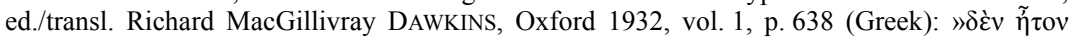
$\pi \mathrm{o} \varepsilon \varepsilon \mu 1 \sigma \tau \dot{\zeta} \varsigma$, p. 639 (English).

8 Leontios Machairas, Recital, ed./transl. DAWKINS (as in n. 7), p. 638-649, quotation on p. 646649. This event is also referred to in Ibn Hağar al-'Asqalānī, inbā al-ġumr bi-anbă al-'umr, ed. Hasan ḢABǍ̌̃, Cairo 1994, vol. 3, p. 342, where the name of the sheikh is given. Cf. Mohamed OUERFELLI, Les relations entre le royaume de Chypre et le sultanat mamelouk au XV siècle, in: Le Moyen Âge 110 (2004), p. 327-344, 337-338.

9 Leontios Machairas belonged to the class of educated Greeks who achieved social prominence in Frankish society. Both he and other members of his family held important positions in the administration of the Lusignans. He was thus a loyal supporter of the ruling dynasty. See Angel Nicolaou-Konnari, Greeks, in: Angel NicolaOU-Konnari, Chris Schabel (eds.), Cyprus. Society and Culture 1191-1374, Leiden 2005 (The Medieval Mediterranean, 58), p. 13-62, here p. 53; Michael PIERIS, The Medieval Cypriot Chronicler Leontios Makhairas. Comments on his Life and Work, in: Johannes G. DeCKERS, Marie-Elisabeth Mitsou, Sabine RoGGE (eds.), Beiträge zur Kulturgeschichte Zyperns von der Spätantike bis zur Neuzeit, Münster 2005 (Schriften des Instituts für Interdisziplinäre Zypern-Studien, 3), p. 107-115, here p. 107-108.

10 For Ibn Qudaydār, see OuERfELLI, Relations entre le royaume de Chypre et le sultanat mamelouk (as in n. 8), p. 337. 
The conquest of Cyprus in 1426 is described in detail in various Arabic sources ${ }^{11}$. The historian Ibn Tagirībirdī, whose father was a Mamluk and who maintained close connections with the sultan's court, presents the Cyprus expedition as a Holy War which all had joined in with great enthusiasm. He claims that it was even possible to recognise the participants from their joyful faces ${ }^{12}$. He describes the homecoming of the victorious troops in particular detail. They marched through Cairo in a triumphal procession from the harbour to the citadel and thence to the sultan. The booty was also presented to the populace, including over 1,000 prisoners, with King Janus riding on a donkey at the end of the procession. After a ransom of 200,000 dinars had been agreed, Janus was released on condition that he should not leave Cairo until the ransom was paid $^{13}$. He was clad in a new garment and received a horse with a golden saddle and brocade housing (kunbūss) for the length of his stay. In addition, the sultan instructed the governor of Cairo to show the king the city and its sights, as well as to entertain him with festive banquets ${ }^{14}$. Ibn Tagirībirdī encountered Janus in person at a meeting and considered him to be an educated, perceptive man, although he admits that he could only presume this since he was not able to communicate directly, given that Janus did not speak any Arabic ${ }^{15}$. What is more, the king visited the Christian churches and holy places in Cairo ${ }^{16}$. Thus, during his stay of several months in the city, Janus had the opportunity to make contact not only with influential emirs but also with Christians of both western and eastern origin. He seems to have developed a special relationship with the sultan's chief translator, since he had 200 ducats sent to him every year for life as thanks for the services which the interpreter had rendered him ${ }^{17}$. If this was so, then contact with high-ranking Mamluks should not have failed because of language difficulties, as they did in the case of Ibn Tagirïirdī.

11 M. Mustafa ZiADA, The Mamlūk Conquest of Cyprus in the Fifteenth Century, in: Bulletin of the Faculty of Arts of the University of Egypt (= mağalla kulliyyat al-ādāb bi 'l-ğāmi'a almișriyya) 1/1 (1933), p. 90-113; ibid., 2/1 (1934), p. 37-57; M. Mustafa ZIADA, John L. LAMONTE, Bedr Ed Din al-'Ayni's Account of the Conquest of Cyprus (1424-1426), in: Annuaire de l'Institut de philologie et d'histoire orientales et slaves 7 (1939-1944), p. 241-264; Louis CHeikHo, Un dernier écho des croisades, in: Mélanges de la faculté orientale, Université Saint-Joseph 1 (1906), p. 303-375; Ibn Tag̉rībirdī, an-nuğūm az-zāhira fī mulūk miṣr wa 'l-qāhira, ed. William POPPER, Berkeley 1920-1923 (University of California Publications in Semitic Philology, 6,2), part VI, 2, p. 599-618; translated as: History of Egypt 1382-1469 A.D., transl. from the Arabic annals of Abu 'l-Mahāsin Ibn Taghrībirdī by William Popper, part IV, 1422-1438 A.D., Berkeley, Los Angeles 1958 (University of California Publications in Semitic Philology, 18), p. 32-45.

12 Ibn Tağrībirdī, an-nuğūm az-zāhira, part VI, 2, p. 600 (Engl., part IV, p. 33) (as in n. 11).

13 Ibid., part VI, 2, p. 612-618 (Engl., part IV, p. 41-45).

14 Badr ad-Dīn al-'Aynī, 'iqd al-ğumān fī tārīh ahl az-zamān, ed. 'Abd ar-Rāziq AṬ-ṬANȚĀWī ALQARMŪT, Cairo 1989, p. 144; ZIADA, LAMONTE, Bedr Ed Din al-'Aini's Account (as in n. 11), p. 263.

15 Ibn Tağrībirdī, an-nuğūm az-zāhira, part VI, 2, p. 620 (Engl., part IV, p. 47) (as in n. 11): »I was present with him in an assembly, and believe that he was a man of discernment and knowledge; this I knew by conjecture only, for he did not know the Arabic language «.

16 Ibid., part VI, 2, p. 620 (Engl., part IV, p. 46-47).

17 Pero Tafur, Travels and Adventures 1435-1439 (The Broadway Travellers), transl. Malcolm LETTS, New York 1926, p. 67. 
From then on, Cyprus was subject to the suzerainty of the sultan, and the Cypriots seem to have fulfilled their obligations. Under Janus' successor, John II (1432-1458), the annual tribute was paid more or less regularly, piracy was stopped, and the Mamluks were granted the right of anchorage during the expeditions of their fleet against the Knights of St. John on Rhodes ${ }^{18}$. Sultan Ināl (1453-1461) even expressly thanked the king in a letter, only recorded in Italian but nonetheless authentic, for the great festival held throughout the kingdom in honour of his assumption of office ${ }^{19}$.

A special relationship existed between the Castilian traveller Pero Tafur and the sultan's head translator mentioned above, who had rendered such good services to King Janus in 1426. According to the account of his journey, Pero Tafur was commissioned by the king of Cyprus in 1437 to convey a message to the sultan. Upon arrival in Cairo, in his function as envoy, he was brought immediately to the head translator, who was apparently the first person to be visited by foreign missions ${ }^{20}$, and was also accommodated at the translator's house. During Tafur's stay, he discovered that the translator also came from Castile, but had moved to Jerusalem, where, after his father's death, he had converted from Judaism to Islam. Pero Tafur had to give news of his homeland to his compatriot and in no time became a friend of the family, so that the translator not only helped him in his business with the sultan but also showed him around the city ${ }^{21}$. The relations with his fellow-countryman, described by Pero Tafur as being particularly cordial, show how original cultural links still continued to have an effect even after a conversion.

With the death of John II in 1458, a dispute over the succession flared up in Cyprus between his daughter Charlotte and her illegitimate half-brother, James the Bastard. First, however, Charlotte was crowned and James fled with a few companions, among them the Arabic-speaking Nasar Chous, to Cairo, where he complained to the ruling Sultan Ināl, as his suzerain, about the injustice he had suffered 22 . However, according to Georgios Boustronios' Greek-Cypriot chronicle, a Mamluk emir, who himself came from Cyprus from the Flatro family, tried to prevent James' recognition as rightful king

18 ZIADA, The Mamlūk Conquest of Cyprus (as in n. 11), vol. 2/1, p. 43-47; FuESS, Verbranntes Ufer (as in n. 2), p. 39-41.

19 Louis de MAS LATRIE, Histoire de l'île de Chypre sous le règne des princes de la maison de Lusignan, Paris 1855, vol. 3, p. 73-75, from 1456.

20 For translators in the service of the Mamluks, see Frédéric BAUDEN, The Role of Interpreters in Alexandria in the Light of an Oath (Qasāma) Taken in the Year 822 A.H./1419 A.D., in: Kristof D'Hulster, Jo VAn Steenbergen (eds.), Continuity and Change in the Realms of Islam. Studies in Honour of Professor Urbain Vermeulen, Leuven 2008 (Orientalia Lovaniensia Analecta, 171), p. 33-63.

${ }^{21}$ Pero Tafur, Travels and Adventures (as in n. 17), p. 72-80.

22 Georgios Boustronios, Diegesis Kronikas Kyproy, ed. Giorgos Kechagioglou, Leukosia 1997 (Kentro epistemonikon ereynon. Peges kai meletes tes Kypriakes historias, 27), p. 68-69; English translation: A Narrative of the Chronicle of Cyprus, 1458-1489, transl. Nicholas COUREAS with supplementary Greek texts of the fourteenth and fifteenth centuries transl. by Hans PoHlsander, Nicosia 2005 (Texts and Studies in the History of Cyprus, 51; Sources for the History of Cyprus, 13), § 36, p. 88. George HiLl, A History of Cyprus, vol. 3: The Frankish Period 1432-1571, Cambridge 1972 (reprint from 1948), p. 548-553. 
by the $\operatorname{sultan}^{23}$. Ibn Tagirībirdī identifies this emir as the sultan's influential secretary, by the name of Burdbak al-Ašrafī, who had been taken prisoner at the age of about 10 or 12 by Ināl during the conquest of Cyprus in 1426, and who had been brought up as a Mamluk. Before Ināl's elevation to sultan, Burdbak had married the latter's sister. Ibn Tagirībirdī also states that Burdbak did not support James' ambitions and that he continued to maintain links with his relatives on Cyprus ${ }^{24}$. His identification of this member of the Flatro family with Burdbak therefore seems justified.

Despite Burdbak's stand, the sultan took James' side and, treating him just like his grandfather Janus, presented him with a garment of honour and a horse with a golden saddle and brocade housing with which (as stated by both Arabic and Cypriot sources) he rode around the city 25 . Whereas Ibn Tagrīibirdī reports quite briefly and factually about James' longer stay in Cairo' ${ }^{26}$, the religious scholar Ibrāhīm b. 'Umar al-Biqā̄î, who is well known for his pious zeal as well as his rather unusual account of history, reports in more detail on James' sojourn. He begins by reproducing the argument of Charlotte, the legitimate successor to the throne, according to which James, because of his illegitimate origin as walad zina a a child of fornication, was not suitable for the office of king. However, the sultan had not been persuaded to change his mind by this, but had pronounced instead that, according to the šari $a$, the Islamic law, it was not permissible for a woman to hold power in Islam. James, described by al-Biqa $\bar{a}^{c} \overline{1}$ as a $\check{s} \bar{a} b$ (young man), had in the meantime whiled away his time by riding through the streets of Cairo in an Egyptian soldier's clothing and making friends with the ğulbān, Mamluks bought by the sultan who were still undergoing training. These ğulbān were well known for the fact that they were prone both to stir up trouble again and again and also to offer resistance to the sultan and emirs ${ }^{27}$. Al-Biqāi then continues with the remark that he himself had heard that these young Mamluks had brought James together with Muslim prostitutes of both sexes. James is also said to have taken part in the traditional festival of opening the side channels of the Nile, a public festival that was regarded by religious scholars as being disreputable, although the sultan is also claimed to have taken part in these dissolute activities. Al-Biqā̄i even asserts that the people had derided

23 Georgios Boustronios, Diegesis Kronikas Kyproy, p. 70-71 (Engl.: § 39, p. 89) (as in n. 22): merchants reported that »Flatro, an emir who happens to be Cypriot, is placing obstacles in his path«. For Flatro see p. 89, n. 79; and Nicholas COUREAS, Mamluks in the Chronicle of George Boustronios and their Place within a Wider Context, in: D'HULSTER, VAN STEENBERGEN (eds.), Continuity and Change (as in n. 20), p. 135-149, here p. 136.

24 Ibn Tag̉rībirdī, an-nuğūm az-zāhira fī mulūk mișr wa 'l-qāhira, ed. William PoPPER, Berkeley 1926 (University of California Publications in Semitic Philology, 7), part VII, p. 544; translated as: History of Egypt, part VI, 1453-1461 A.D., transl. William POPPER, Berkeley, Los Angeles 1960, p. 100; ID., muntaḩabāt min ḥawādit ad-duhūr fĩ madā 'l-ayyām wa ’š-šuhūr, ed. William POPPER, part 1: 845-856 A.H., Berkeley 1930 (University of California Publications in Semitic Philology, 8,1), p. 330.

25 Florio Bustron, Chronique de l'île de Chypre, ed. Louis de MAS LATRIE, Paris 1886, p. 392.

26 Ibn Tağrībirdī, an-nuğūm az-zāhira, part VII, p. 520-522; (Engl., part VI, p. 87-88) (as in n. 24).

27 ZIADA, The Mamlūk Conquest of Cyprus (as in n. 11), vol. 2/1, p. 48. For the chroniclers' low estimation of the gulbān, see Amalia LevanONI, A Turning Point in Mamluk History. The Third Reign of al-Nāṣir Muhamammad Ibn Qalāwūn (1310-1341), Leiden 1995, p. 100-101. 
James in the streets on account of his alleged homosexual relationship with the sul$\tan ^{28}$. In brief, al-Biqāi pulls out all the stops to discredit James from a pious Muslim's point of view, an attack that was certainly due, in part, to the fact that al-Biqa $\bar{c} \overline{1}$ was a confidant of Burdbak ${ }^{29}$.

When Ināl finally threatened Charlotte to give up her claim to the throne, the queen sent a mission to Cairo in 1460 to persuade the sultan to change his mind. According to the Cypriot historian Georgios Bustronios, she succeeded in this; obviously the many presents presented by her emissaries contributed to her success. Accordingly, her envoys were promised that on the next day, during an audience, the official appointment of Charlotte as Queen of Cyprus would be pronounced by the sultan. On hearing this, James was beside himself. However, one of his confidants worked on the emirs throughout the night, together with the above-mentioned Nasar Chous, because he spoke Arabic ${ }^{30}$. Apparently James was able to outbid Charlotte so that a memorable scene took place at the audience on the following day, one which was recorded in both Muslim and Cypriot writings, and far beyond that. When Charlotte's envoys were handed a garment of honour as a sign of her appointment ${ }^{31}$, a tumult broke out among the young Mamluks, whom James had obviously befriended. They wrested the garment from the Cypriot envoys and shouted that only James was king. When Burdbak wanted to put an end to this uproar, they insulted him by saying that he was himself a `Frank and was taking the side of the Franks. This shows that, during his stay in Cairo, James had managed to establish himself as the representative of friendship with the Mamluks, whereas the Mamluk Burdbak was regarded disrespectfully as a $>$ Frank account of his Cypriot origin! In the end, the sultan was forced to give way and to recognise James as the rightful ruler. A short time later, James embarked with Mamluk troops to Cyprus to assume power there. However, it was to take four years before he ultimately succeeded in achieving his objective, with the help of the Mamluks ${ }^{32}$.

James II rewarded his comrades-in-arms, including some Mamluks, with the grant of fiefs. The list of the supporters rewarded by him contained in an Italian chronicle of

28 Ibrāhīm Ibn 'Umar al-Biqā̄ī, iẓhār al-'aṣr li-asrār ahl al-'aṣr, ed. Muhammad Sālim B. ŠADĪD AL-'AWFī, vol. 3, Riyad 1993, p. 81-83.

${ }^{29}$ Li GuO, al-Biqāî̄'s Chronicle. A Fifteenth Century Learned Man's Reflections on His Time and World, in: Hugh KENNEDY (ed.), The Historiography of Islamic Egypt (c. 950-1800), Leiden, Boston, Cologne 2001 (The Medieval Mediterranean, 31), p. 121-148, esp. p. 128.

30 Georgios Boustronios, Diegesis Kronikas Kyproy, p. 72-75; (Engl., § 41, p. 90-91) (as in n. 22); COUREAS, Mamluks in the Chronicle of George Boustronios (as in n. 23), p. 137-138.

31 For the robe, see COUREAS, Mamluks in the Chronicle of George Boustronios (as in n. 23), p. 137.

32 Ibn Taġrībirdī, an-nuğūm az-zāhira, part VII, p. 520-522, 544-546; (Engl., part VI, p. 87-88, 100-101) (as in n. 24). Georgios Boustronios, Diegesis Kronikas Kyproy, p. 72-75; (Engl., $\S 42$, p. 91) (as in n. 22), just states: »and as they took the robe in order to put it on the emissary [of Charlotte] suddenly the Mamluks all [shouted] with one voice >Long live King James!< and, snatching the robe, put it on the postulant [i.e. James] «; COUREAS, Mamluks in the Chronicle of George Boustronios (as in n. 23), p. 138; FuESS, Verbranntes Ufer (as in n. 2), p. 47-50. 
Cyprus includes one Feres Mamaluco and a certain Gioan Cercasso, the Circassian ${ }^{33}$. Benjamin Arbel succeeded in finding the latter mentioned in two documents in the Venetian State Archive, permitting a more precise identification ${ }^{34}$. This Mamluk, now called Joannes Cerchassus, had submitted a petition to the Venetian Senate in 1496, after Cyprus had been taken over by Venice, according to which he had spent many years on the island, probably during the civil war, in the retinue of James II. On his return to the Mamluk sultanate he had left four sons behind in Cyprus, of whom the eldest one, Petrus, had assumed the fief granted to his father. He was now asking for a pecuniary fief, as was usual in Cyprus, for his three younger sons, Paris, Thomas, and Domenicus. At the same time, this Mamluk announced that he would soon be appointed viceroy of Damascus, which might or might not be to the advantage of Venice. Accordingly, the Senate agreed to his request. This emir was thus by no means a Joannes, or Jean or similar, but rather the Mamluk Ğān Balāt, who in the meantime had risen to the highest circles in the Mamluk ruling system and who, in 1500, was even to hold the office of sultan, if only for six months. All this was notwithstanding the fact that his sons lived in Cyprus and were clearly Christians, as their names prove. That did not, however, prevent Ğān Balāt from continuing to further the fortunes of his family. In another petition, Ğān Balāt alias Zuan Cercasso successfully requested that the confiscation of a village, to which one of his sons was entitled, be revoked. Requests for further improvements were rejected in spite of the fact that the emir had equipped his sons with horses and weapons so that they, too, could perform military service for the Signoria. He did at least succeed, however, in achieving the conferment of an administrative post upon his son-in-law, who had a large family to care for and who would otherwise have been destitute ${ }^{35}$.

Thus a viceroy of Damascus and future sultan presents himself here as the caring head of his Christian family living in Cyprus, with which he was apparently in regular contact and to which he gave financial support. In the Arabic sources, which document Ğān Balāt's activity as governor of Jerusalem, viceroy of Damascus, and sultan in the usual manner (and mostly favourably), no information of any kind is to be found about his double life across the existing religious and cultural boundaries. Rather it is reported that he had married the widow of Sultan Qāyitbāy in 1496, precisely at the time of his petitions to the Signoria ${ }^{36}$. Whether the epithet Cercasso, which became the family name of his Cypriot family, did indeed denote his origin or simply represented a general designation for Mamluks cannot be clarified. However, it does seem to me that

${ }_{33}$ Florio Bustron, Chronique de l'île de Chypre (as in n. 25), p. 418; Benjamin ArBel, Venetian Cyprus and the Muslim Levant, 1473-1570, in: EdBury, Cyprus and the Crusades (as in n. 5), p. 174; COUREAS, Mamluks in the Chronicle of George Boustronios (as in n. 23), p. 145-146.

34 ARBEL, Venetian Cyprus and the Muslim Levant (as in n. 33), p. 174-175; COUREAS, Mamluks in the Chronicle of George Boustronios (as in n. 23), p. 146-147.

35 ARBEL, Venetian Cyprus and the Muslim Levant (as in n. 33), p. 175-177.

36 Muhammad b. Aḥmad b. Iyās, Die Chronik des Ibn Ijās, ed. Mohamed Mostafa, Cairo, Wiesbaden ${ }^{2} 1963$ (Bibliotheca Islamica, 5c), part 3: AH 872-906 (AD 1468-1501), p. 439, 444. 
Ğān Balāt, whose life as Mamluk was shaped by the experience of a transfer from one culture to another, was especially prepared to surmount cultural boundaries.

In conclusion, it cannot be doubted that the fundamental orientation of Mamluk policy was to the East, since an active and continuous naval policy was not pursued and the Mediterranean trade was left to Western European merchants. However, it is possible to show how, at a personal (but not necessarily private) level, many and diverse relations and networks did exist and were cultivated between the Mamluk sultanate and Cyprus. The exchange connected with this led, at least for a time, to a blurring of the contours of cultural affiliation and identity, as in the cases of James II (regarded as the friend of the Mamluks), Burdbak (reviled as being a >Frank $\iota$ ), and Ǧān Bālāt (the Mamluk who simultaneously was a Muslim statesman and the head of a Christian Cypriot family). Such cases provide the material necessary for the task of making the plurality and religious diversity of a pre-modern Islamic world and its fully fledged integration into the world of the Eastern Mediterranean visible again. To be reminded of this seems to be of particular importance today, when this plurality is being both lost and increasingly denied. 
